\title{
ALDH1A1 Gene
}

National Cancer Institute

\section{Source}

National Cancer Institute. ALDH1A1 Gene. NCI Thesaurus. Code C116056.

This gene is involved in the metabolism of retinal. 